\title{
Inflammatory Bowel Diseases: the Surgical Perspective
}

\author{
Bogdan SOCEA ${ }^{1}$, Dan DUMITRESCU², Ovidiu Gabriel BRATU ${ }^{3}$, Alexandru Constantin CARAP', \\ Dumitru Cristinel BADIU ${ }^{4}$, Alexandra BOLOCAN ${ }^{5}$, Dan Nicolae PADURARU ${ }^{5}$, Dan MISCHIANU ${ }^{3}$, \\ Vlad Denis CONSTANTIN ${ }^{7}$
}

\begin{abstract}
Inflammatory bowel diseases (IBD), namely Crohn's disease and ulcerative colitis, are relatively rare diseases in our country, known as a low prevalence geographic region. IBD are a multidisciplinary problem, that implies gastroenterologists, as well as surgeons. Surgical management in inflammatory bowel disease is often impaired by a high complication rate and a significant recurrence rate, specific mostly for Crohn's disease. Indications for surgery include failure of medical therapy (including delayed puberty for young patients and drug intolerance), toxic megacolon, bowel perforation, obstruction, enteric fistula and abdominal or perianal abscess. Advances in medical treatment options for IBD are continuously accumulating. However, a large number of patients still require surgical procedures during lifetime.
\end{abstract}

Keywords: inflammatory bowel disease, Crohn's disease, ulcerative colitis, surgery.

\section{Rezumat}

Bolile inflamatorii intestinale, cuprinzând boala Crohn și colita ulcerativă, sunt boli relativ rare în țara noastră, cunoscută ca o regiune geografică cu prevalență scăzută. Bolile inflamatorii intestinale reprezintă o problemă multidisciplinară, care implică atât gastroenterologi, cât și chirurgi. Abordarea chirurgicală în bolile inflamatorii intestinale este adesea afectată de o rată ridicată a complicațiilor și de o rată semnificativă de recurență, specifică mai ales pentru boala Crohn. Indicațiile intervențiilor chirurgicale includ eșecul terapiei medicamentoase (inclusiv pubertatea întârziată pentru pacienții tineri și intoleranța la medicamente), megacolonul toxic, perforațiile intestinale, ocluzia, fistula enterică și abcesul abdominal sau perianal. Opțiunile de tratament medicamentos în bolile inflamatorii intestinale se perfecționează continuu. Cu toate acestea, un număr mare de pacienți încă necesită proceduri chirurgicale de-a lungul vietii.

Cuvinte cheie: boli inflamatorii intestinale, boala Crohn, colita ulcerativă, chirurgie.

\footnotetext{
1 Department of Surgery, "Sf. Pantelimon" Emergency Clinical Hospital, „Carol Davila" University of Medicine and Pharmacy, Bucharest, Romania

${ }^{2}$ Department of Surgery, University Clinical Hospital, „Carol Davila" University of Medicine and Pharmacy, Bucharest, Romania

${ }^{3}$ Department of Urology, Central Military Clinical Hospital, „Carol Davila" University of Medicine and Pharmacy, Bucharest, Romania

${ }^{4}$ Department of Surgery, "Carol Davila" University of Medicine and Pharmacy, „Bagdasar-Arseni” Emergency Clinical Hospital, Bucharest, Romania

${ }^{5}$ Department of Surgery, "Carol Davila" University of Medicine and Pharmacy, Emergency University Hospital, Bucharest, Romania
}

\section{Corresponding author.}

Bogdan Socea, Department of Surgery, „Sf. Pantelimon” Emergency Clinical Hospital, Bucharest, Romania.

E-mail: bogdansocea@gmail.com

Note: All the authors equally contributed to this manuscript 


\section{INTRODUCTION}

Ulcerative colitis (UC) and Crohn's disease (CD) are inflammatory intestinal diseases, grouped together in the entity of inflammatory bowel diseases (IBD). These conditions have both overlapping and distinct clinical and pathological features, and pathogenesis is yet incompletely understood. Genetic and environmental factors are suspected to alter intestinal immunity, being promoters of gastrointestinal injury ${ }^{1-6}$.

Surgical morbidity and better functional outcome and quality of life (QOL) are all important objectives of the management of these diseases.

The incidence and prevalence of inflammatory bowel diseases (IBD) are continuously increasing all over the world, indicating a tendency of becoming world spread diseases ${ }^{7}$. Romania is enrolling in the global trend of increasing incidence, although geographically it does not represent an area with high prevalence. The incidence of UC has been increasing in previously low-incidence areas i.e. Eastern Europe, Asia, and developing countries $^{1}$. IBD have low incidence in Asia and in Southern Europe $^{8}$. A high incidence of IBD is encountered in the northern areas, such as northern Europe and North America ${ }^{9}$ IBD occur more frequent in Caucasian people $^{10}$. UC is more frequent in men, while $\mathrm{CD}$ is more common in women ${ }^{11}$.

Despite the fact that medical treatment has continuously improved during the last decade, $80 \%$ of patients with Crohn's disease $(\mathrm{CD})^{12}$ and approximately $25-35 \%$ of patients with ulcerative colitis (UC) require surgery during their lifetime ${ }^{13,14}$. IBD represent a model of multidisciplinary management. Timing of surgery represents the key issue for proper management of IBD patients.

\section{Surgical indications and options}

For acute and some specific cases of severe IBD, surgery can be a vital procedure.

Many studies suggest that patients with IBD have an increased risk for developing myocardial infarction and stroke $e^{15,16}$. In addition, these patients are at high risk of developing cardiovascular events in the perioperative period, and they are in need for a specific anesthesia and intensive care management, especially related to surgery ${ }^{17-19}$.

\section{Crohn's disease}

Crohn's disease primarily involves the small bowel, inflammation including the entire intestinal wall. The intentions of surgical treatment in Crohn's disease cannot be curative, as it is a pan-enteric disease. Surgical indications are mainly related to complications (fibrostenotic or perforated disease) and limited exertion surgery is recommended. Seriate interventions can cause short bowel syndrome, with the severe consequence of malnutrition ${ }^{20,21}$. Thus, small bowel resection segments should be limited as much as possible or even avoided. A bowel-sparing surgery as part of philosophy of conservationism becomes the rule, and, in consequence, different techniques of strictureplasties are searched for small bowel fibrous strictures.

Strictureplasty techniques in CD are chosen in order to preserve bowel function, whenever these procedure is feasible and the disease is limited. Nowadays, there are several described techniques for strictureplasty. The most common are Heineke-Mikulicz for short strictures, Finney for longer strictures, and Michelassi sideto-side isoperistaltic for multiple sequential strictures ${ }^{22}$. Several authors reported new types of strictureplasties: Fazio and Tjandra ${ }^{23}$ and Poggioli ${ }^{24}$.

According to European Crohn's and Colitis Organisation (ECCO) guidelines „Strictureplasty is a safe alternative to resection in jejunoileal Crohn's disease, including ileocolonic recurrence, with similar short-term and long-term results" 25 .

However, resection of a small bowel segment remains the most commonly performed procedure in $\mathrm{CD}^{26}$. Recurrence rates tend to increase with the passage of time and $C D$ patients may eventually require multiple resections, each increasing the risk of shortbowel syndrome. No correlation seems to be between the extension of resection and relapse of the disease. Thus, extensive "radical" resections, with healthy tissue margins are not necessary ${ }^{27,28}$.

\section{Ulcerative colitis}

Ulcerative colitis affects the large bowel in most cases, with inflammation being restricted to the mucosa. The surgical treatment aims to obtain healing, with the possibility of resection of the entire affected segment (total rectocolectomy). This intervention prevents development of colorectal cancer over time, lowering the risk of malignancy.

Strictureplasties are not recommended for large bowel stenosis.

The main emergency indications for surgical intervention in UC include massive hemorrhage, toxic colitis, toxic megacolon, and intestinal perforation. Elective indications include medically refractory UC, intoleran- 
ce or non-adherence to medical therapy, severe malnutrition, the presence of dysplasia, and cancer ${ }^{27,29,30}$.

Total abdominal colectomy and end ileostomy is the procedure of choice in emergency settings ${ }^{31}$. The most frequent elective procedure performed for $\mathrm{UC}$ is restorative proctocolectomy with (RPC) with ileal pouchanal anastomosis (IPAA), which is considered the gold standard $^{30}$. Total proctocolectomy removes all disease and eliminates the risk of colorectal cancer ${ }^{32}$. Unfortunately, total proctocolectomy with end ileostomy is associated with significant morbidity (complications related to ileostoma, sexual dysfunction, altered bladder function) $)^{33}$.

IPAA was first described by Sir Allen Parks at St. Marks Hospital London in the early 1980's. Construction of ileal pouch offers long-term restoration of intestinal continuity without permanent ileostomy. The pouch remains functional for 20 years in $90 \%$ of patients $^{34}$. In IPAA, the rectal stump mechanically stapled to ileal pouch remains of minimal lengths $(2 \mathrm{~cm})$, so that the risk of subsequent rectal cancer is minimum.

ECCO guidelines state that „If surgery is necessary for localized colonic disease (less than a third of the colon involved), then resection only of the affected part is preferable”25. They also state that „Two segmental resections can be considered for a patient with an established indication for surgery when macroscopic disease affects both ends of the colon" 25 .

Minimal invasive surgery (MIS) proved to have at less same positive results compared to classic surgery in cases of inflammatory bowel diseases. There are no in- creased risk of complications for MIS, and the advantages of laparoscopy are obvious ${ }^{35-37}$.

Recent studies also revealed the role of probiotics in selected patients. The outcome of UC patients with restorative proctocolectomy and ileal pouch was by probiotics.

\section{CONCLUSIONS}

Surgical management in IBD is mandatory for the further outcome and treatment, as well as for patient's quality of life. It often proves to be complex, because clinical outcomes are different and decision making are challenging and difficult. Intraoperative decision of surgical tactics and techniques requires experience. A good multidisciplinary collaboration is necessary for best results, and to decide the best surgical timing.

Recently, laparoscopic surgery proved an increasing role in IBD, especially for elective cases. It is necessary that experienced and dedicated IBD surgeons to perform it, in a multidisciplinary approach.

IBD are proinflammatory and hypercoagulable conditions, with high perioperative risks.

\section{Compliance with ethics requirements:}

The authors declare no conflict of interest regarding this article.

The authors declare that all the procedures and experiments of this study respect the ethical standards in the Helsinki Declaration of 1975, as revised in 2008(5), as well as the national law. Informed consent was obtained from all the patients included in the study.

\section{References}

1. Bernstein $\mathrm{CN}$, Fried $\mathrm{M}, \mathrm{Krabshuis} \mathrm{JH}$, Cohen $\mathrm{H}$, Eliakim $\mathrm{R}, \mathrm{Fe}-$ dail S, et al. World Gastroenterology Organization Practice Guidelines for the diagnosis andmanagement of IBD in 2010. InflammBowel Dis 2010; 16: 112-24.

2. Nasim S, Chawla T, Murtaza G. Surgical management of inflammatory bowel disease: A low prevalence, developing country perspective. J Pak Med Assoc 2016; 66(3): 247-250.

3. Neagu TP, Țigliş M, Popescu A, Enache V, Popescu ŞA, Lascăr I. Clinical, histological and therapeutic modern approach of Ledderhose disease. Romanian Journal of Morphology and Embryology 2018; 59(3): 691-7.

4. Mirea DA, Mirea LE, Nitipir CO, Țigliş M, Grințescu IC, Neagu TP, Mogoanță CA, Grințescu IM. Non-Hodgkin's lymphoma, rare localization at the base of the tongue-case presentation. Rom J Morphol Embryol 2017; 58(3): 1077-81.

5. Neagu TP, Tigliş M, Botezatu D, Enache V, Cobilinschi CO, Valcea-Precup MS, Grințescu IM. Clinical, histological and therapeutic features of Bowen's disease. Romanian Journal of Morphology and Embryology 2017; 58(1): 33-40.

6. Radulescu D, Checherita IA, Peride I, Ginghina O, Niculae A, David C, Vacaroiu I. Fp438 incidence and risk factors for prolonged hungry bone disease after parathyroidectomy in dialyzed patients. Nephrology Dialysis Transplanation 2015 May 1; 30(suppl_3): iii217.

7. Molodecky NA, Soon IS, Rabi DM, Ghali WA, Ferris M, Chernoff $G$, et al. Increasing Incidence and Prevalence of the Inflammatory Bowel Diseases With Time, Based on Systematic Review. Gastroenterology 2012; 142(1): 46-54.

8. Ye Y, Pang Z, Chen W, Ju S, Zhou C. The epidemiology and risk factors of inflammatory bowel disease. Int J Clin Exp Med 2015; 8(12): 22529-22542.

9. Burisch J, Munkholm P. The epidemiology of inflammatory bowel disease. Scand J Gastroenterol 2015; 50(8): 942- 951.

10. Ng SC, Shi HY, Hamidi N, Underwood FE, Tang W, Benchimol El, Panaccione R, Ghosh S, Wu JCY, Chan FKL, Sung JJY, Kaplan GG. Worldwide incidence and prevalence of inflammatory bowel disease in the 21 st century: a systematic review of population-based studies. Lancet 2018; 390(10114): 2769- 2778. 
11. Hanauer SB. Inflammatory bowel disease: epidemiology, pathogenesis and therapeutic opportunities. Inflammatory Bowel Disease 2006; 12: S3-S9.

12. Gardiner KR, Dasari BV. Operative management of small bowel Crohn's disease. Surg Clin North Am 2007; 87: 587-610.

13. Larson DW, Pemberton JH. Current concepts and controversies in surgery for IBD. Gastroenterology 2004; 126(6): 1611-1619.

14. Guindi M, Riddell RH. Indeterminate colitis. J Clin Pathol 2004; 57: 1233-44.

15. Filimon AM, Negreanu L, Doca M, Ciobanu A, Preda CM, Vinereanu D. Cardiovascular involvement in inflammatory bowel disease: dangerous liaisons. World J Gastroenterol 2015; 21(33): 9688-9692.

16. Manea M, Marcu D, Motofei I, Socea B, Pantea Stoian A, Bratu OG, Gaman MA, Gaman AM, Stanescu AMA, Diaconu CC. Cardiovascular risk in patients with inflammatory bowel diseases: a review. Romanian Biotechnological Letters 2019; DOI: 10.26327/RBL2019.257.

17. Checherita IA, David C, Ciocalteu I, Lascar I. Management of the chronic renal patient undergoing surgery. Chirurgia 2009; 104(5): 525- 530.

18. Tiglis M, Grintescu IC, Neagu TP, Turcu FL, Cocolos AM, Grintescu IM. Sugammadex: What to know for your daily practice. Rev Chim 2018; 69(2): 391-395

19. Tiglis M, Mirea LE, Ungureanu R, Grintescu IC, Neagu TP, Grintescu IM. How Complicated a Complicated Case Can Become?. Modern Medicine. 2017;24(3):143.

20. Ciuhu AN, Pantea-Stoian AM, Popescu M, et al. Nutrition and drug interventions in short bowel syndrome by definitive abdominal stoma in cancer patients, 3rd International Conference on Interdisciplinary Management of Diabetes Mellitus and its Complications (INTERDIAB) Location: Bucharest, ROMANIA Date: MAR 02-04, 2017, INTERDIAB 2017: DIABETES MELLITUS IN INTERNAL MEDICINE Book Series: International Conference on Interdisciplinary Management of Diabetes Mellitus and its Complications, p.148-155.

21. Ciocirlan, Maria; Draghia, Loredana; Manuc, Daniela; et al. Nutritional Status Of Patients With Digestive Cancers,Conference: 3rd International Conference on Interdisciplinary Management of Diabetes Mellitus and its Complications (INTERDIAB) Location: Bucharest, ROMANIA Date: MAR 02-04, 2017, INTERDIAB 2017: DIABETES MELLITUS IN INTERNAL MEDICINE Book Series: International Conference on Interdisciplinary Management of Diabetes Mellitus and its Complications 2017; 132-138.

22. Solina G, Mandala S, La Barbera C, Mandala V. Current management of intestinal bowel disease: the role of surgery. Updates Surg 2016; DOI: 10.1007/s13304-016-0361-4.
23. Fazio VW, Tjandra JJ. Strictureplasty for Crohn's disease with multiple long strictures. Dis Colon Rectum 1993; 36: 71-72.

24. Poggioli G, Laureti S, Pierangeli F, Ugolini F. A new model of strictureplasty for multiple and long stenoses in Crohn's ileitis: side-to-side diseased to disease-free anastomosis. Dis Colon Rectum 2003; 46:127-130.

25. Dignass A, et al. European Crohn's Colitis Organisation (ECCO) The second European evidence-based Consensus on the diagnosis and management of Crohn's disease: current management. J Crohns Colitis 2010; 4: 28-62.

26. Williams JG, Wong WD, Rothenberger DA, Goldberg SM. Recurrence of Crohn's disease after resection. Br J Surg 1991; 78 . 10-9.

27. Roses RE, Rombeau JL. Recent trends in the surgical management of inflammatory bowel disease. World $\mathrm{J}$ Gastroenterol 2008; 14(3): 408-412.

28. Valcea S, Enciu O, Pantu C, Vartic M, Neagu TP, Beuran M. Multivisceral Resection for Pancreatic Adenocarcinoma. Case Report and Literature. Modern Medicine 2017; 24(1):35.

29. Ross H, Steele SR, Varma M, et al. Practice parameters for the surgical treatment of ulcerative colitis. Dis Colon Rectum 2014 57: 5-22.

30. Holubar SD, Privitera A, Cima RR, et al. Minimally invasive total proctocolectomy with Brooke ileostomy for ulcerative colitis. Inflamm Bowel Dis 2009; 15: 1337-1342.

31. Cohen JL, Strong SA, Hyman NH, Buie WD, Dunn GD, Ko CY, et al. Practice parameters for the surgical treatment of ulcerative colitis. Dis Colon Rectum 2005; 48: 1997-2009.

32. Hwang JM, Varma MG. Surgery for inflammatory bowel disease. World J Gastroenterol 2008;14(17): 2678-90.

33. Cornish JA, Tan E, Teare J, Teoh TG, Rai R, Darzi AW, et al. The effect of restorative proctocolectomy on sexual function, urinary function, fertility, pregnancy and delivery: a systematic review. Dis Colon Rectum. 2007; 50(8): 1128-38.

34. Hahnloser D, Pemberton JH, Wolff BG, et al. Results at up to 20 years after ileal pouch-anal anastomosis for chronic ulcerative colitis. Br J Surg 2007; 94: 333-340.

35. Olson CH. Single-Site Laparoscopic Surgery for Inflammatory Bowel Disease. JSLS 2014; 18: 258-264.

36. Holder-Murray J, Marsicovetere P, Holubar SD. Minimally Invasive Surgery for Inflammatory Bowel Disease. Inflamm Bowe Dis 2015; 21: 1443-1458.

37. Timofte D, Ciuntu B, Bulgaru Iliescu D, et al. Laparoscopic Sleeve Gastrectomy is Associated with Reduced Depressive Symptoms: A One-Year Follow-Up Study. Revista De Cercetare Si Interventie Sociala 2017; 61: 147-154. 